\title{
DECISION SUPPORT SISTEMS (DSS) DETERMINING DEPARTMENT USING NAIVE BAYESIAN ALGORITHM
}

\author{
Nurlindasari Tamsir ${ }^{1}$, Samsu Alam² \\ ${ }^{1}$ STMIK Dipanegara Makassar, Indonesia \\ stmik14@gmail.com ${ }^{1}$

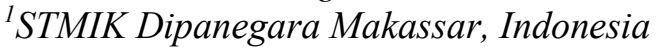 \\ alam@dipanegara.ac.id ${ }^{l}$
}

\begin{abstract}
In practice the majors are often determined by the teacher with consideration of academic achievement and ignore the interests and talents of the students. Students who have high scores on the grades of report cards will be educated on IPA and low achievers will be led to IPS and Language. Problems faced by most schools because students who enter the majors are not in accordance with the skills, abilities, interests and talents of students that affect the quality and success of student learning. With the majors in accordance with the characteristics of personality, students will feel happy when learning so as to help prepare students to continue their studies and choose the world of work and help strengthen the achievements to be achieved in the future. The purpose of this study is to find out how the implementation of Decision Support Sistems (DSS) using the Naive Bayesian method in determining the department in accordance with the skills, abilities, interests and talents of students held in SMA Negeri 10 Makassar and SMA Islam Athirah Makassar. Technique of data retrieval is done by observation and direct interview. The instrument used is a validated questionnaire by 2 (two) validators to test the questionnaire validity. There are two types of data that are analyzed ie student value data and questionnaire data that generate interest and talent of students to determine the direction. It is expected that with this application it can be seen that the students go to the department has been in accordance with the potential of each student.
\end{abstract}

Keywords: Athirah, DSS, Naive Bayesian, SMAN 10.

\section{INTRODUCTION}

Education is a universal phenomenon in people's lives. This fact is caused because education is a life phenomenon that cannot be separated from other social phenomena. In this connection, the family (parents/guardians), schools, and the community have a reciprocal relationship (interaction) that touches each other in the formal process of child education. Because all three institutions are directly responsible for the child's future. Therefore, all three must walk together, support each other, motivate and influence each other for the success of education to be achieved.

The meaning of the department is very principle by some parents/guardians, so they influence it, because according to him the department can create a better atmosphere by considering the possibilities as a symbol of success. In this pattern of thinking, the meaning of the department is none other than the way parents/guardians express themselves and the way he seeks the right relation to the world around him as a manifestation of the success of education, new success will be achieved if it gets strong motivation from the educational supporters. Parent/guardian behavior is an intellectual act, which is an action that is influenced by lust, psychological needs or emotional conditions. Included in this action for example parents/guardians in interpreting the department. The behavior of parents tends to reject the school-determined majors.

The aim of majors is so that in the future, the lessons that will be given to students become more targeted because they are in accordance with their interests. The BK/BP teachers have usually done psychological tests so far that the potential for students to be psychologically more dignified and the majors to be conducted are not misdirected. However, many parents force their children to enter science.

Even though the school process has been decided by the school through a teacher meeting. So, if the student's score is less than the standard that has been set then he must enter the IPS or Language department. In school education, each student's differences must be considered because it can determine the good and bad student achievement [1]. Correspondingly, Reference [2] argues, that a fundamental school goal is to develop all the talents and abilities of students, during the education process to reach the level. Individual differences between students in schools include differences in cognitive abilities, achievement motivation, interests and creativity [1].

Snow further pointed out that because of these individual differences, the function of education is not only in the teaching and learning process, but also includes guidance and counseling, selection and placement of students in accordance with the individual capacity that is owned, the design of appropriate teaching systems and customized teaching strategies with individual characteristics of students [1].

Therefore, schools play an important role to be able to develop the self-potential of students. Chances that will occur if students experience errors in majors are low student achievement or can cause anxiety in self-actualization.

Thus, students who learn a science that matches the characteristics of their personality (interest in a particular science) will feel happy when learning the science. Other research shows that personality factors positively influence 
academic achievement. Thus majors are not a matter of intelligence but a problem of student interest and talent. Interests as understood and used by people so far can affect the quality of achieving student learning outcomes in certain fields of study.

Students' differences in interest will determine career choices in the future. Majors in high school students become the starting point that determines the profession in the future. According to the 2003 National Education System Law concerning the purpose of secondary education, there are 2 directions that are carried out taking into account the orientation of students, namely:

a. Continuing to higher education into the Natural Sciences study program, Social Sciences, or Language Studies according to interest after graduating from high school.

b. Working in the community; majors are one of the placement or distribution processes in the selection of teaching programs for high school students. In this department, students are given the opportunity to choose the department that best matches their characteristics. The accuracy of choosing a department can determine the success of student learning. Conversely, a very good opportunity for students will be lost because of lack of accuracy in determining the direction.

While the aim of majors includes:

a. Group students according to skills, abilities, talents, and interests that are relatively the same.

b. Helps prepare students to continue their studies and choose the world of work.

c. Helping strengthen the success and suitability of the achievements that will be achieved in the future (study continuation and the world of work).

In practice majors are often determined by the teacher with consideration of academic achievement only and ignore the interests and talents of students. Students who have a high score on the value of the automatic report card will be directed to the Natural Sciences and vice versa for students with low achievement will be directed to Social Sciences and Languages

Though the high value in a lesson does not show interest, and vice versa. And what needs to be underlined is that students who are referred to their Natural Sciences, Social Sciences or Linguistics are both unique, special and potential. If the teacher or community considers students who are in the social studies department are students who have no potential, then that is a big mistake. Science, Social Sciences and Language Sciences both need their own expertise and both require interest and intelligence.

So parents and teachers should be wise in this direction. Parents and teachers should invite students to recognize their own interests and potential while being directed accordingly. If students are interested in entering the social studies department, the teacher and parents should encourage and support it, and vice versa.

Based on the description that has been stated, then in this study the main problems that will be the focus of attention are: "How to implement the Decision Support System (DSS) into an information system using the Naive Bayesian method to determine majors that are appropriate to the interests, talents of students in public high schools 10 Makassar and Athirah Makassar Islamic High School?"

By referring to the formulation of the problem as mentioned above, the objectives of this research are: "To find out how the implementation of Decision Support Systems (DSS) uses the Naive Bayesian method in determining majors according to interests, talents of students in SMA 10 Makassar and Athirah Islamic High School Makassar ".

As for some other research titles related to the same problem. Publication manuscript with the title of Information System Majoring in SMA Negeri 1 Klirong Kebumen. SMA Negeri 1 Klirong is a school that still uses manual systems in the process of majors, so the authors developed this system into a computerized based system. This application aims to make it easier for users to do the majors for high school students of class $\mathrm{X}$ who will go up to class XI. This majors system requires several assessment criteria, such as report card grades, aptitude test results, and student interest. The high school majors system is carried out at the end of semester 2 of class X. The process of majors is usually carried out by the teacher or homeroom teacher and the counseling teacher (Counseling Guidance). Each homeroom teacher will provide report cards or final grades of all subjects, then be submitted to the BK teacher to be analyzed and ranked and based on students' interest in the department. This application uses Microsoft Visual Basic 6.0 and SQL Server 2000 [3].

National Seminar with the Title of Decision Support System for Selection of Programs in High School with Fuzzy Logic. To support the above, it is necessary to have a decision support system that is able to provide support for the process of determining the appropriate department for students in high school. The process of determining this department by considering the abilities, talents and interests of students towards a department, by using fuzzy logic. This high school student majors decision support system was built using Borland Delphi ver. 7.0 and Microsoft Access 2003 as the database [4].

National Seminar with the title Information System for Selection of Departments in Kendal 1 Vocational High School Based on Decision Support System Using Simple Additive Weight (SAW) Method. The purpose of this study is to develop a decision support system that has the ability to choose a study department at SMK N 1 Kendal using the SAW method and this decision support system is expected to produce recommendations for the selection of majors for prospective students of SMK N 1 Kendal so that it is easier to get the right majors based on the ability of prospective students [5].

Based on several previous studies that have similar problems with the authors' research it was concluded that there were no studies using the Naïve Bayesian method.

\section{METHOD}

In conducting a research, research planning is needed so that the research carried out can run well, systematically and effectively. There are three common steps in designing a system. These stages consist of system analysis, system design and system implementation.

The form of system redesign that the authors propose is shown in Fig. 1. 
Supporting data from the school environment starting with students and homerooms. For homeroom students, grades collected in the form of odd semester students 'grades in class $\mathrm{X}$ and for students are given in the form of student questionnaires to determine students' interests and talents in a particular department. For values and questionnaires, each is entered in a different database. so that the database does not produce the average value of students to calculate student grades obtained from the homeroom teacher and the results of the questionnaire are to determine students' interests and talents. Furthermore, the data (mean value and questionnaire) are reprocessed using the Decision Support System collected by the Naive Bayesian algorithm. From the results of the DSS, the results are obtained for the students.

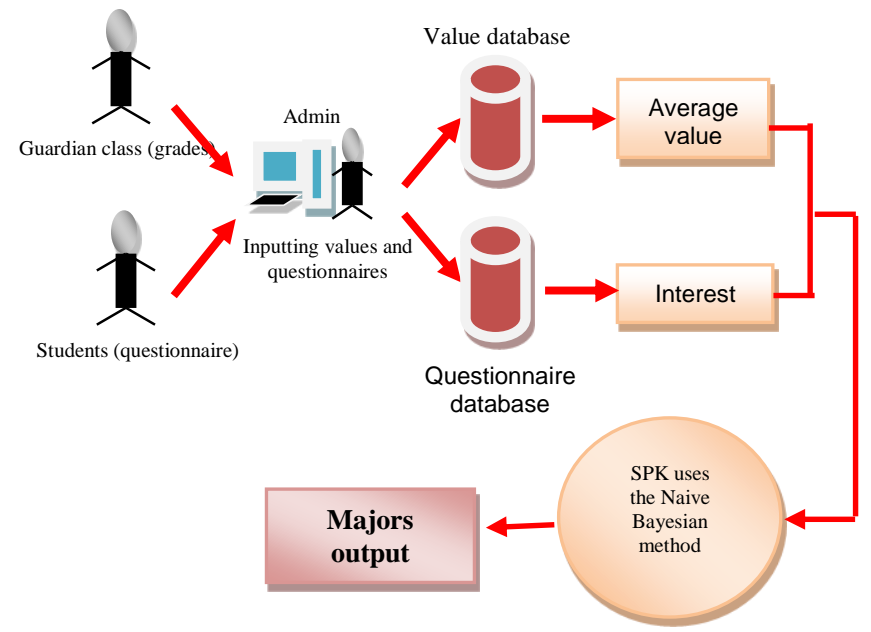

Fig. 1. Reengineering System Design

\section{A. System Analysis}

The data analysis technique in this study was in the form of a choice of department and SPK questionnaires using the Naive Bayesian algorithm.

a. Validity data analysis questionnaire. The validation results of the experts were analyzed by considering the assessment, input, comments and suggestions from the validator. Based on the data from the validity assessment results from two validators / experts, then the mean values of $\mathrm{V} 1$ and $\mathrm{V} 2$ are calculated, with $\mathrm{V} 1=$ the average value obtained from the first validator and $\mathrm{V} 2=$ the average value obtained by the second validator. Furthermore, it was confirmed with the interval of determining the questionnaire category (Darwis, 2007), namely:
$\mathrm{V}<1.5$
$1.5 \leq \mathrm{V}<2.5$
$2.5 \leq \mathrm{V}<3.5$
$3.5 \leq \mathrm{V}<4.5$
$4.5 \leq \mathrm{V}$
means invalid
means it is less valid
means it's quite valid
means it is valid
means it's very valid.

Description: $\mathrm{V}$ is the validity of the instrument.

The criteria used to decide that the instrument has an adequate degree of validity is the value of $\mathrm{V}$ for all minimum aspects in the "quite valid" category. If this is not the case then it needs to be revised based on the validator's advice or by looking back on aspects that are of less value. Next, re-validation was performed and then re-analyzed.
Likewise, until the minimum value of $\mathrm{V}$ is in the "valid" category.

b. SPK data analysis. In this study using a decision support system by designing an application that uses the Naïve Bayesian algorithm. Then, the data that has been collected will be processed into software that has been designed to produce a decision.

\section{B. Research Instruments}

Data collection methods are ways or ways used by researchers to collect data in research. Data collection methods in the study according to [6] are broadly divided into two, namely tests and non-tests. The technique used is the nontes technique which is an assessment tool used to obtain information about the condition of the testee without a test tool. Nontes technique is used to obtain data that is not or at least directly related to cognitive behavior [7].

In this study using questionnaires in data collection. Questionnaire is a number of written questions that are used to obtain information from respondents in the sense of a report about his personality, or things he knows. The purpose of using questionnaires in this study was to reveal students' learning interests both before being subjected to treatments and after being subjected to tretmen.

According to [8], classified the questionnaire into four, namely open and closed questionnaires, scale, check list, and ranking form. While [6] classified the questionnaire as follows:

a. Based on the way of answering, it can be divided into two, namely open questionnaire and closed questionnaire.

b. Based on the answers given are divided into two, namely direct questionnaire and indirect questionnaire.

c. Viewed from its form it can be divided into four, namely multiple choice questionnaires, entries, check lists, and rating scales.

TABLE 1

Instrument Lattice (Selection of Major Variable)

\begin{tabular}{l|l|l|l}
\hline \multirow{4}{*}{ Aspect } & \multirow{2}{*}{ Indicator } & \multicolumn{2}{c}{ Item } \\
\cline { 3 - 4 } & & Favourable & $\begin{array}{c}\text { Unfavourab } \\
\text { le }\end{array}$ \\
\hline $\begin{array}{l}\text { Interest in } \\
\text { Natural } \\
\text { Science }\end{array}$ & - Affective & $1,3,5,7$ & $2,4,6,8$ \\
\cline { 2 - 4 }$S$ & - Psychomotor & $9,11,13,15$ & $10,12,14,16$ \\
\cline { 2 - 4 } $\begin{array}{l}\text { Interest in } \\
\text { IPS }\end{array}$ & - Cognitive & $17,19,21,23$ & $18,20,22,24$ \\
\cline { 2 - 4 } & - Affective & $25,27,29,31$ & $26,28,30,32$ \\
\hline \multirow{2}{*}{$\begin{array}{l}\text { Language } \\
\text { Interest }\end{array}$} & - Psychomotor & $33,35,37,39$ & $34,36,38,40$ \\
\cline { 2 - 4 } & - Cognitive & $41,43,45,47$ & $42,44,46,48$ \\
\cline { 2 - 4 } & - Psfective & $49,51,53,55$ & $50,52,53,56$ \\
\cline { 2 - 4 } & - Cognitive & $57,59,61,63$ & $58,60,62,64$ \\
\hline
\end{tabular}

\section{Population and Sample}

The population in this study were all class $\mathrm{X}$ students of SMA Negeri 10 Makassar and Athirah Makassar High School. Students at SMA Negeri 10 Makassar, amounting to 360 students, are divided into 9 classes whose distribution is based on the highest score of the school entrance test. 
While students at Athirah Makassar Islamic High School total 240 students who are divided into 8 classes that are randomly distributed.

The technique used in sample support is probability sampling. Probability sampling is a sample support techniques that provide equal opportunities for each element (member) of the population to be selected as a member of the sample [9]. This technique includes simple random sampling. It is said to be simple because the supporting members of the sample from the population are done randomly without regard to the strata in the population. This method is carried out if members of the population are considered homogeneous.

Sample support from this population is class X5 SMA Negeri 10 Makassar and class X1 Islamic High School Athirah, because each class is considered homogeneous (the same) then the writer only takes one class from each school.

\section{Grade promotion}

a. The increase in class is carried out at the end of each school year or every even semester.

b. The increase in class is based on the assessment of learning outcomes in the even semester, with consideration of all SK / KD that have not been completed in the odd semester, must be completed until reaching the specified KKM, before the end of even semester. This is in accordance with the principle of complete learning (mastery learning), where participants who have not achieved mastery learning in accordance with the defined KKM then the concerned must take remedial learning until the person is able to achieve the intended KKM.

c. Students are stated not to have elevated grade XI, if they do not reach the minimum level of study, more than 3 (three) subjects.

d. Students are not considered to have gone up to class XII, if the student does not reach the minimum level of study, more than 3 (three) subjects which are not subject to program characteristics or those who do not attain complete learning at least one or more typical subjects program.

For example: IPA Program, should not have a value that is not complete in the subjects of Physics, Chemistry and Biology. The social studies program cannot have incomplete grades in the subjects of Geography, Economics and Sociology. Language Program, must not have an incomplete value in the subjects of Anthropology, Indonesian Literature and other foreign languages that are the choice.

\section{E. Majors}

a. Time of determination and implementation of majors: Determination of majors and for students for the Natural Sciences, Social Sciences and Languages program is carried out from the end of semester 2 (two) class $X$ and the implementation of KBM is in accordance with the majors program, starting in semester 1 (one) class XI.

b. Program majors.

Determination of program majors is carried out by considering the potential, interests and needs of students, which must be proven by academic achievement results in accordance with the criteria set by the education unit. If there is a difference between the potential / interest in the academic value of a student, then the teacher must review and make improvements in providing learning services to those concerned.

Students who go up to class XI and those who get an incomplete score 3 (three) subjects, then the value must be used as a basis to determine the program that can be followed by students, for example:

1. If subjects that are not complete are Physics, Chemistry and Geography (2 subjects typical of the Natural Sciences program and 1 characteristic of the IPS program), then the student can be academically admitted to the Language program.

2. If the subjects that are not complete are Indonesian, English and Physics (2 subjects that are typical of the Language program and 1 characteristic of the Natural Sciences program), then the student can academically be included in the IPS program.

3. If the subjects that are not complete are Economics, Sociology and English (2 subjects typical of the IPS program and 1 characteristic of the Language program), then the student can be academically admitted to the Natural Sciences program.

4. If the subjects that are not complete are Physics, Economics and Indonesian Language (covering all subjects that are characteristic of the three programs in high school) then the students: It is necessary to pay attention to the interests of students and attention to achievement of knowledge, practices and attitudes to the eyes lessons that characterize the Natural Sciences program such as Physics, Chemistry and Biology compared to subjects that are characteristic of the Social Studies program (Economics, Geography, Sociology) and compared to subjects that are characteristic of the Language program (Indonesian, English). Comparison of student achievement scores can be done through a remedial program and ends with an exam. If the value of each subject that characterizes a particular program there is an achievement value that is superior to other programs, then the student can be directed to a program whose achievement scores are superior. If between the three interests and achievements of the three aspects are not suitable / appropriate, the homeroom teacher with consideration of input from the guidance and counseling teacher can decide what program the student chooses.

c. For students who meet the requirements to enter all programs, given the opportunity to move majors if they are not suitable for the original program or not in accordance with the ability and progress of learning. Schools must facilitate so that students can achieve basic competency and competency standards that must be possessed in a new class.

d. The deadline for moving programs is determined by the school no later than 1 (one) month.

e. The education unit can add majors criteria according to the characteristics and needs of each education unit.

\section{F. Interest}


Interest is the tendency of a fixed soul to pay attention and remember some activities or activities [2]. Someone who is interested in dealing with an activity and paying attention to it consistently with pleasure.

According to [10], interest is the moment-moment of the tendency of the soul that is directed intensively to an object that is considered the most effective (feeling, emotional) in which there are effective elements (emotions) that are strong. Interest is also related to personality, so the interest in getting the elements of recognition (cognitive), emotional (affective) and ability (conative) to reach an object, someone a problem or a situation concerned with personal self [11].

According to [12], interest is a high heart tendency toward something that arises because of needs, perceived or not felt or desires of certain things. Interest can be interpreted as a tendency to be interested or motivated to pay attention to someone's goods or activities in certain fields [13].

\section{G. Interest is divided into 3 aspects}

According to Hurlock, 1995: 117 interest is divided into:

a. Cognitive Aspects. Based on personal experience and what has been learned both at home, school and community and various types of mass media.

b. Affective Aspects. The concept that builds cognitive aspects, expressed interest in attitudes towards activities arising from interest. Develops from personal experience from the attitude of important people, namely parents, teachers and peers towards activities related to these interests and attitudes expressed or implied in various forms. mass media on the activity.

c. Psychomotor aspects. Run smoothly without thinking, the order is right. But progress is still possible so that flexibility and excellence increase even though this is all slow.

\section{H. System}

System testing is done to find out if the software that has been built is right to be ready to be implemented or used by the user. The test in this study uses the Naive Bayesian algorithm where the data tested is value data and questionnaire data and then tests using a white box where the system is tested so that it is free from logical errors.

\section{RESULTS AND DISCUSSION}

\section{A. SMPN 10 Makassar}

The determination of majors is held after the class increase is carried out first. In determining the class increase that applies at SMA Negeri 10 are (1) If there are 4 (four) subjects that are not complete or do not reach the KKM (Minimum Completeness Criteria), (2). Attendance is $80 \%$, (3). Cognitive aspects (attitudes) of students.

Constraints that are sometimes experienced by schools in terms of determining class increases are if there are students whose grades exceed 4 (four) subjects do not reach the KKM but the attendance of the students concerned reaches $80 \%$ or more. So, the curriculum with BK, students and the teacher council hold a meeting or discussion to consider the student can go up to class XI.

In determining the majors in SMA 10, the conditions are:

a. Academic value. The first consideration of the school in determining majors is academic value. Academic values that are considered are the cognitive aspects of even semester students. A student must achieve the KKM for each subject in the Science and Social Sciences program. The subjects that must be diluted for the Natural Sciences program are mathematics, physics, chemistry and biology, while the subjects that must be diluted for social studies programs are economics, history and sociology.

b. Teacher observation. The second condition of determining majors in SMA Negeri 10 is to look at the results of teacher interviews in the field of science and social studies programs for students. So, each teacher in the Natural Sciences and Social Sciences study program sees or observes student development since odd semester. The development in question is how students behave towards the teacher, friends and environment, how students tend to certain subjects, how active students are in certain subjects.

c. Questionnaire. The distribution of questionnaires by BK for students is held after the final semester exam. Questionnaires are only distributed to students to be known by parents, the school does not facilitate questionnaires for parents.

\section{B. Hadji Kalla Islamic Education and Welfare Foundation}

Before making prior majors determination of class increase. The system that runs in Athirah Islamic High School in determining the grade increase is based on the assessment of learning outcomes in the even semester. A student who is declared not in class if the score does not reach the KKM in one or more typical subjects of the Natural Sciences or Social Sciences program and more than 3 (three) subjects that are not typical subjects of the Science and Social Sciences program.

Determination of class increase in Islamic High School Athirah sometimes experience obstacles if the value of a student is not complete or does not reach the KKM. So, with other considerations the school considers the affective aspects of the student. Affective aspects reflect students' attitudes and behaviors during the period of 1 semester. If the affective aspect of the student is very good, then the school still provides the opportunity for the student concerned to go up to the class with a record of trying to improve the incomplete value in the eleventh grade increase.

After determining the increase in class by looking at the cognitive aspects and the affective aspects of students, the division or determination of majors can be carried out. There are several steps in determining the majors that apply at Athirah Islamic High School, namely:

a. Quota. In determining the department, it is done by paying attention to the class quota. In this case, before the curriculum together with the BK issued a decision on the determination of majors for students to first pay attention to the quota of each class for science and social studies. The quota for each science and social science class is 30 students 
with 3 classes of science and social studies. So, the quota for IPS is 90 students and the quota for science is 90 students.

b. Questionnaire. Before determining the division of majors for the students concerned. Athirah Islamic High School has distributed questionnaires to students. The questionnaire contains questions that represent students' interests so that it is known that the student is interested in science or social studies. The school does not distribute questionnaires to parents because the school really does pay attention to students' interests. Whereas to determine the talent of students, class $\mathrm{X}$ at the beginning of the odd semester the school has given a psychological test.

c. Academic value. After paying attention to the quota and questionnaire, the next division is based on student rankings by paying attention to the even semester student report card grades.

\section{Data Analysis Results}

The results of the study with the Naive Bayesian algorithm for the problem of selecting majors are done by analyzing the data, namely the students' scores and student questionnaires. To analyze it first, prior information is shown in Table 2.

TABLE 2

Class XI Student Data for grades and questionnaires

\begin{tabular}{lccc}
\hline & IPA & IPS & $\begin{array}{c}\text { LANG } \\
\text { UAGE }\end{array}$ \\
\hline IPA $>$ 65 & & & 99 \\
IPA $<\mathbf{6 5}$ & 100 & 71 & 21 \\
\hline IPS > 65 & 20 & 49 & 94 \\
IPS $<\mathbf{6 5}$ & 83 & 87 & 26 \\
\hline LANGUAGE > 65 & 37 & 33 & 75 \\
LANGUAGE < 65 & 74 & 110 & 45 \\
\hline IPA = S Questionnaire & 46 & 10 & 81 \\
IPA = TS Questionnaire & 113 & 71 & 39 \\
\hline IPS = S Questionnaire & 7 & 49 & 94 \\
IPS = TS Questionnaire & 94 & 109 & 26 \\
\hline LANGUAGE=S Questionnaire & 83 & 11 & 96 \\
LANGUAGE=TS Questionnaire & 37 & 32 & 24 \\
\hline
\end{tabular}

D. Value and questionnaire analysis using the Naive Bayesian algorithm

Value analysis by calculating the average value of the program majoring in Natural Sciences, Social Sciences and Languages, while the majority-based questionnaire answers the program indicators for science, social studies and language programs which state agree or disagree. The author takes the case of a student named Esar Alfian.
TABLE 3

Average Value of Esar Alfian Students

\begin{tabular}{c|c|c|c}
\hline \multirow{2}{*}{ Name } & \multicolumn{3}{|c}{ Average Value } \\
\cline { 2 - 4 } & IPA & IPS & Language \\
\hline Esar Alfian & 69,3 & 69,3 & 61 \\
\hline
\end{tabular}

TABLE 4

Esar Alfian Student Questionnaire Data

\begin{tabular}{c|c|c|c}
\hline \multirow{2}{*}{ Name } & \multicolumn{3}{|c}{ Questionnaire } \\
\cline { 2 - 4 } & IPA & IPS & Language \\
\hline Esar Alfian & TS & S & TS \\
\hline
\end{tabular}

TABEL 5

Rekomendasi SPK

\begin{tabular}{c|c|c|c|c}
\hline \multirow{2}{*}{ No } & \multirow{2}{*}{ Nama Siswa } & \multicolumn{3}{|c}{ Rekomendasi SPK } \\
\cline { 3 - 5 } & & IPA & IPS & $\begin{array}{c}\text { BAHAS } \\
\text { A }\end{array}$ \\
\hline 1. & Esar Alfian & 215.0 & 244,3 & 102,3 \\
\hline
\end{tabular}

\section{E. Analysis of majors with SPK}

Based on the results of the calculation of values and questionnaires using the Naive Bayesian algorithm obtained the percentage of opportunities for each department program (Science, Social Sciences, Language). Based on Table 5, it can be seen that students named Esar Alfian get the largest percentage of opportunities in the social studies department. The results are in the form of department recommendations that have been designed with SPK.

Based on the results of the calculation of the value of the case example it was found that the student named Esar Alfian was eligible to enter the science and social studies majors. Whereas based on the results of questionnaire calculations it was found that Esar Alfian fulfilled the requirements to enter the Department of Social Sciences.

Analysis of majors that are built is by paying attention to the value of the student. If the score meets the requirements of the subjects that are characteristic of the Natural Sciences, Social Sciences and Languages program, the results of the SPK are the results of the analysis of the values. If there is an equal value in 2 (two) program majors, the questionnaire will be executed. After being calculated using Naive Bayesian, the questionnaire is obtained so that the SPK is the result of the questionnaire.

The system design that is built is based on students' interests with value considerations. Thus, the final result of the SPK that was built was "a student named Esar Alfian was eligible to enter the social studies department."

The implementation of the conditions or requirements of the SPK determination of majors in SMA based on the flowchart can be seen in Fig. 2. This is in line with the program lines shown in Fig. 3. 


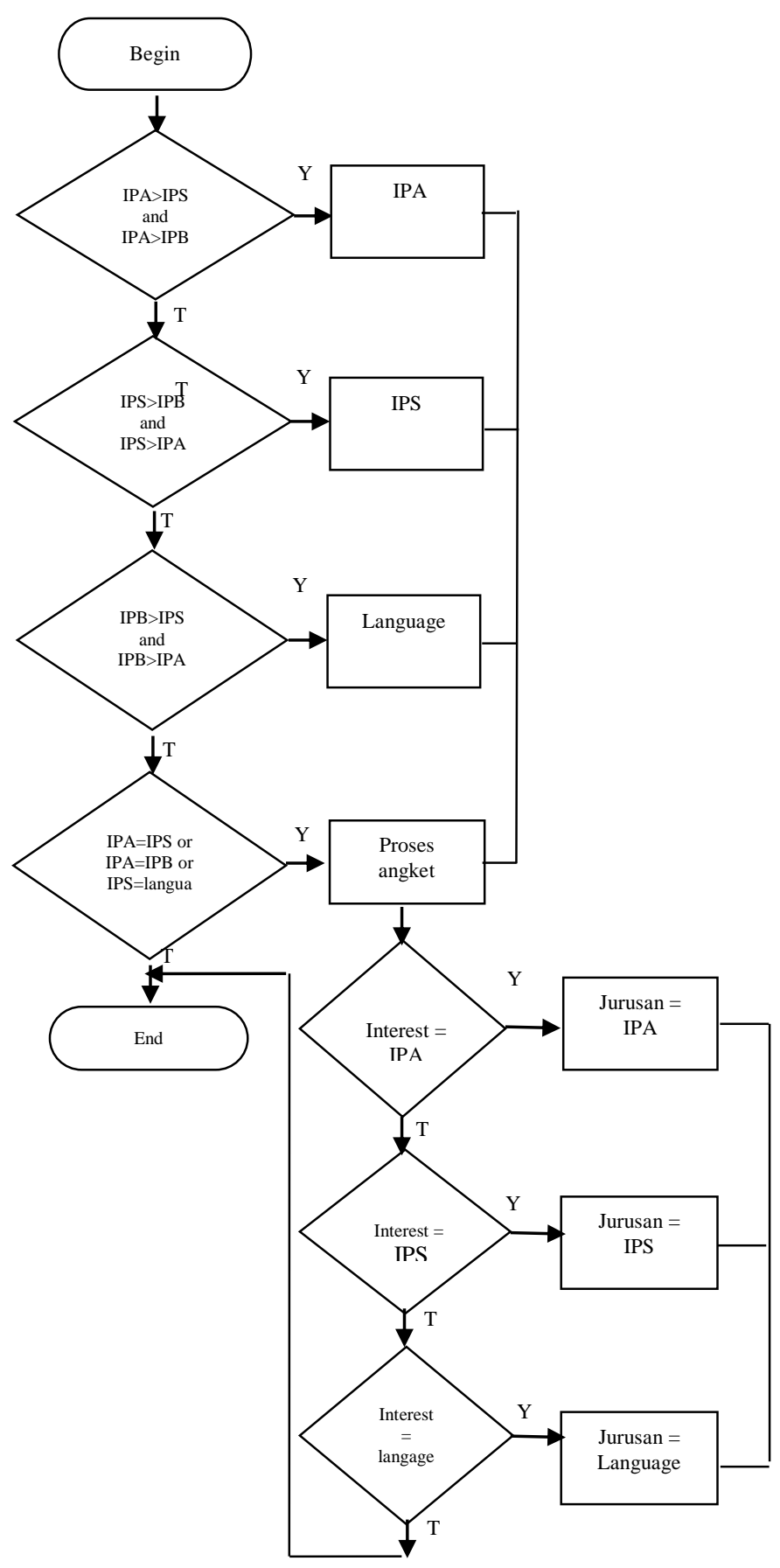

Fig. 2. Conditions or Requirements for SPK Determination of Departments based on flowchart

From the results of the value data and questionnaire data it was concluded that manually the case sample with the name of Esar Alfian students was determined to be in the social studies department.

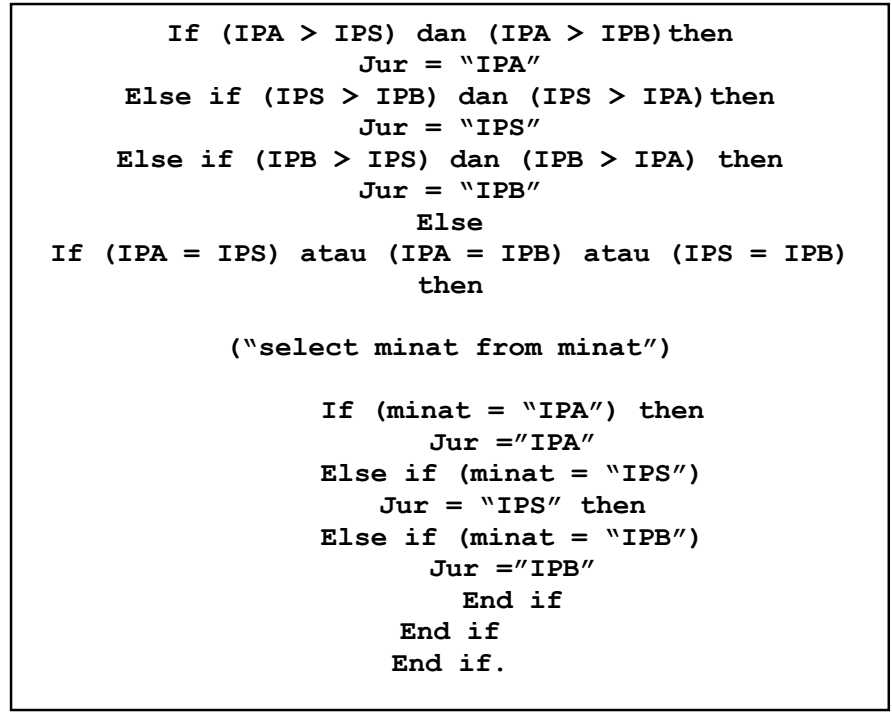

Fig. 3. Conditions or Requirements for SPK Determination of Departments based on program lines

As verification of the designed application, the manual results obtained are in accordance with the application as in Fig. 4.

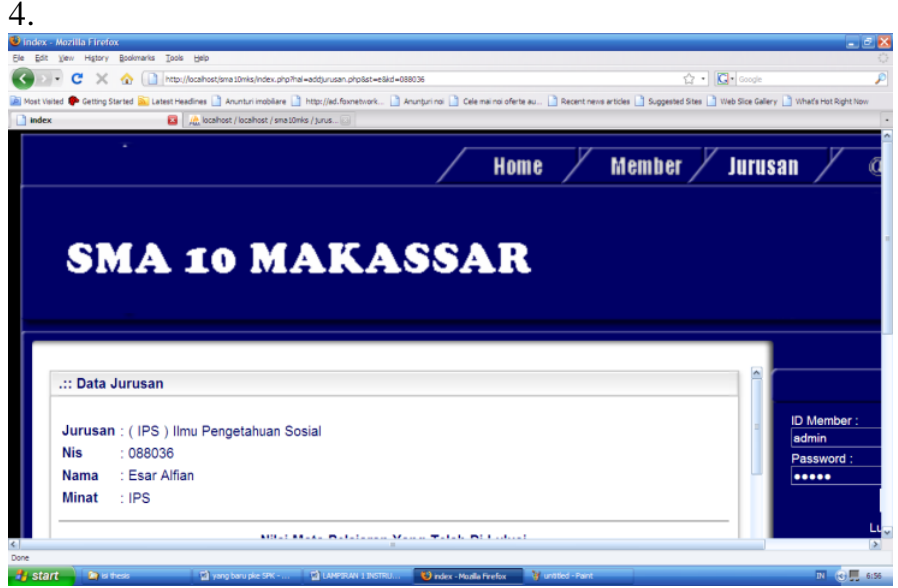

Fig. 4. Student SPK results named Esar Alfian

\section{F. White box testing}

To get a software design with good results from a design of the built-in SPK, the writer does the testing using the white box shown in Table 6.

From the results of flowgraph analysis with the base path test method, the test results analysis system is free from logical errors, because three parameters, namely region, independent path, and complexity have the same value. 
TABLE 6

Analysis of Test Results with the White Box

\begin{tabular}{l|c|c|c}
\hline $\begin{array}{l}\text { Proses } \\
\text { Flowgraph }\end{array}$ & Region & $\begin{array}{l}\text { Independent } \\
\text { Path }\end{array}$ & $\begin{array}{l}\text { Kompl } \\
\text { eksitas }\end{array}$ \\
\hline Menu utama & 16 & 16 & $\mathbf{1 6}$ \\
\hline Home Admin & 3 & 2 & $\mathbf{2}$ \\
\hline Member Admin & 3 & 3 & $\mathbf{3}$ \\
\hline Member Admin Siswa & 3 & 3 & $\mathbf{3}$ \\
\hline $\begin{array}{l}\text { Member Admin Nilai } \\
\text { Member Siswa } \\
\text { Angket }\end{array}$ & 3 & 3 & $\mathbf{3}$ \\
\hline $\begin{array}{l}\text { Member Siswa } \\
\text { Jurusan }\end{array}$ & 3 & 3 & $\mathbf{3}$ \\
\hline $\begin{array}{l}\text { Member } \\
\text { Identitas }\end{array}$ & 3 & 3 & $\mathbf{3}$ \\
\hline $\begin{array}{l}\text { Member Siswa Angket } \\
\text { Member }\end{array}$ & 2 & 2 & $\mathbf{3}$ \\
\hline Jurusan & $\mathbf{4 2}$ & $\mathbf{4 2}$ & $\mathbf{3 2}$ \\
\hline Jurusan & & & \\
\hline About & 3 & $\mathbf{2}$ \\
\hline Total & & 3 & \\
\hline
\end{tabular}

\section{IV.CONCLUSION}

The conclusions that can be drawn from this study are as follows:

1. The analysis technique consists of 2 (two) data, namely the validity of the data analysis questionnaire which shows that the instrument is very valid and analyzes the SPK data using the Naive Bayesian algorithm.

2. Based on the results of research on 2 (two) high schools, namely SMA Negeri 10 Makassar and Athirah Islamic High School Makassar that in the selection system majors both apply academic values and questionnaires as a condition in determining majors.

3. The results of the SPK majors analysis design show that for an example of a case a student named Esar Alfian fulfilled the requirements to enter the Social Sciences department.

4. Based on the results of system testing using the Naive Bayesian algorithm shows that manual calculation and application into the program produces the same data. Whereas for testing the system using the white box, it is free from logic errors because the region, independet path and cyclomatic complexity parameters have the same value.

5. Percentage of errors in SPK results with data in the field at Makassar 10 SMA showing 7.5\% (of 40 students) or as many as 3 (three) students who chose different majors with the results of the SPK. While the percentage of errors in SPK results with data in the field at the Athirah Makassar Islamic High School shows 3.3\% (of 30 students) or as many as 1 (one) student who chooses a different department with the results of the SPK.

\section{ACKNOWLEDGEMENT}

The author would like to thank the schools of SMA Negeri 10 Makassar and Athirah Makassar High School for providing opportunities and information both directly and indirectly so that the authors can carry out this research. Likewise for other parties who have helped this research process starting from data collection so that this research can be completed.

\section{REFERENCES}

[1] S. R. E, "Individual Differences and the Design of Educational Programs," Journal of Psychology, 1986.

[2] S. I. Santoso, Character Development, Jakarta: Universitas Indonesia, 1979.

[3] T. Munfaikoh, "Majoring Information System at State Senior High School 1klirong Kebumen," Amikom, Yogyakarta, 2011.

[4] H. C. R. Y. I. Hafsah, "Decision Support System Selection of Programs in High School with Fuzzy Logic," in Informatics National Seminar 2008 (semnasIF 2008), 2008, 2008.

[5] A. Z. Moh. Muthohir, "Information system Selection of Departments in SMK N 1 Kendal Based on Decision Support System Using Simple Additive Weight Method (SAW)," in National Computer Science Seminar (SNIK 2015), Semarang, 2015.

[6] A. Suharsimi, An Approach Research Procedure Practicum, Jakarta: Rineka Cipta, 1998.

[7] B. Nurgiyantoro, Writing in Language and Literature Teaching, Yogyakarta: BPFE, 1987.

[8] I. Hadjar, The Basics of Quantitative Research Methodology in Education, Jakarta: Raja Grafindo Persada, 1999.

[9] Sugiyono, Educational Research Methods, Bandung: Alfabeta, 2008.

[10] Kartono, Child Psychology (Developmental Psychology), Bandung: CV Mandar Forward, 1996.

[11] M. Buchori, Educational Psychology, Jakarta: New Script, 1985.

[12] M. A. Hardjana, Tips for Successful Study in Higher Education, Yogyakarta: Kanisius, 1994.

[13] Loekmono, Learn how to learn, Jakarta: BPK Gunung Mulia, 1994. 